See discussions, stats, and author profiles for this publication at: https://www.researchgate.net/publication/340247620

\title{
Hepatozoon Infecting Bats in the Southeastern Brazilian Rainforest
}

Article in Journal of wildlife diseases · March 2020

DOI: 10.7589/2019-08-216

CITATIONS

0

7 authors, including:

Roberto Do Val Vilela

Fundação Oswaldo Cruz

20 PUBLICATIONS 111 CITATIONS

SEE PROFILE

Some of the authors of this publication are also working on these related projects:

Environmental surveillance of Spotted Fever in Brazil View project

Tinamídeos do Brasil View project
Stefan Vilges de Oliveira

Universidade Federal de Uberlândia (UFU)

156 PUBLICATIONS 561 CITATIONS

SEE PROFILE 


\title{
SHORT COMMUNICATIONS
}

\section{Hepatozoon Infecting Bats in the Southeastern Brazilian Rainforest}

\begin{abstract}
Elizabeth C. F. Santos, ${ }^{1,2,5}$ Nicole O. Moura-Martiniano, ${ }^{1,5}$ Roberto V. Vilela, ${ }^{3}$ Camila S. Lucio, ${ }^{3}$ Ademar F. Silva, ${ }^{1}$ Stefan V. Oliveira, ${ }^{4}$ and Gilberto S. Gazeta ${ }^{1,2,6}$ 'Laboratory of National Reference for Rickettsiosis Vectors, Oswaldo Cruz Foundation, Av. Brasil, 4365/Pav. Lauro Travassos, Anexo Posterior, Sala 8-Manguinhos. 21045-900, Rio de Janeiro, Rio de Janeiro, Brazil; ${ }^{2}$ Graduate Program in Biodiversity and Health, Oswaldo Cruz Foundation, Av. Brasil, 4365/Pav. Arthur Neiva, Secretaria Acadêmica-Manguinhos, 21045-900, Rio de Janeiro, Rio de Janeiro, Brazil; ${ }^{3}$ Laboratory of Biology and Parasitology of Reservoir Wild Mammals, Oswaldo Cruz Foundation, Av. Brasil, 4365/Pav. Lauro Travassos, Sala 70-Manguinhos, 21045-900, Rio de Janeiro, Rio de Janeiro, Brazil; ${ }^{4}$ Faculty of Medicine, Federal University of Uberlandia, Uberlandia, Av. Pará, 1720/Bloco 2U, Sala 8-Campus Umuarama, 38405320, Uberlândia, Minas Gerais, Brazil; ${ }^{5}$ These authors contributed equally to this work; ${ }^{6}$ Corresponding author (email: gsgazeta@ioc.fiocruz.br)
\end{abstract}

ABSTRACT: Tick-borne protozoans of the genus Hepatozoon are obligate hemoparasites that can infect domestic and wild terrestrial vertebrates. Main hepatozoonosis affects canids and involves mainly Hepatozoon canis and Hepatozoon americanum. However, molecular studies revealed the capacity of $H$. canis to infect a wide range of wild mammals. In July 2018, we conducted an epidemiological survey for tick-borne pathogens in wild hosts, assaying Hepatozoon sp. occurrence of in 34 bats captured in different habitats within a conservation unit in the state of Espírito Santo, southeastern Brazil. Blood and spleen tissue DNA samples were submitted to PCR amplifications of Babesia/Theileria and Hepatozoon 18S rRNA gene and 21\% (7/34) were positive for Hepatozoon sp. Phylogenetic inferences grouped the obtained sequences from Seba's short-tailed bat (Carollia perspicillata) with the $H$. canis cluster, and from the great fruit-eating bat (Artibeus lituratus) with rodent-associated Hepatozoon cluster. Further studies are needed to characterize the epidemiological role of Seba's short-tailed bat and the great fruit-eating bat in the wild transmission cycle of these hemoparasites in Brazil.

Key words: Bat, hemoparasite, protozoa, southeast Brazil, tick-borne pathogen.

The genus Hepatozoon comprises obligate hemoparasites that can infect domestic and wild terrestrial vertebrates. The Hepatozoon life cycle has a definitive hematophagous invertebrate host, and an intermediate vertebrate host (Serra-Freire 1979; Alencar et al. 1997; Dantas-Torres 2008), which becomes infected through a trophic cycle involving the ingestion of infected invertebrates or vertebrate prey, which can lead to hepatozoonosis (Smith 1996; Almeida et al. 2013; Maia et al, 2014).
Hepatozoonosis affects canids and typically involves Hepatozoon canis and Hepatozoon americanum, whose transmission occurs by ingestion of infected ticks (Rubini et al. 2005; Demoner et al. 2016). However, molecular studies revealed the potential of $H$. canis to infect a wide range of wild mammals such as the white-eared opossum (Didelphis albiventris), hoary fox (Pseudalopex vetutus), and bush dog (Speothos venaticus; Silva et al. 2017). The first evidence of Hepatozoon infection in Chiroptera was during a molecular survey of Trypanosoma sp. in mammals' tissues, which resulted in detection of Hepatozoon sp. in fawn leaf-nosed bat (Hipposideros cervinus) from Malaysia, without sequencing (Pinto et al. 2013). In Brazil, although molecular studies have shown the occurrence of Hepatozoon species in wild canines and felids, rodents, coatis, marsupials, crocodiles and amphibians (André et al. 2010; Azevedo et al. 2018; Perles et al. 2019), Hepatozoon-like organisms were detected in Chiroptera (by morphological analysis) in little yellow-shouldered bat (Sturnira lilium) from São Paulo state (Torres et al. 1983).

Between 28 July and 10 August 2018, an epidemiological survey was conducted for tick-borne pathogens inhabiting wild hosts and, in this study, we evaluate the occurrence of Hepatozoon in bats captured in different habitats types from a biological reserve of Espirito Santo state, southeastern Brazil. During an epidemiological survey of Babesia occurrence, field expeditions were conducted to collect ectoparasites, blood, and spleen tissues from bats, in the Biological Reserve of 


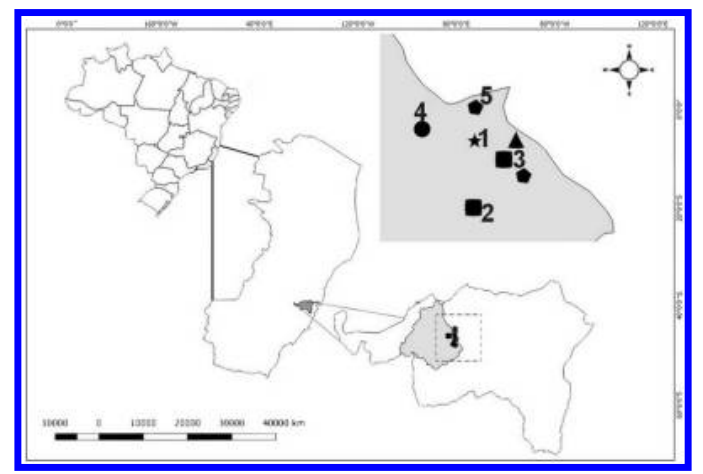

Figure 1. Map of Brazil (A), highlighting Espírito Santo State (B), at Brazil's Southeast Region, with the municipality of Cariacica underlined (C), emphasizing the investigated sites of bat sampling in Duas Bocas Biological Reserve (D), during the babesiosis epidemiologic research in July 2018. The numbers indicate the collection sites within the Reserve: accommodation for researchers (1 and 2), anthropized area trail (3), preserved forest trail (4), and cave with pipes (5). The bat species captured are indicated as: square, Artibeus lituratus; pentagon, Carollia perspicillata; triangle, Desmodus rotundus; star, Molossus rufus; and circle, Myotis lucifugus.

Duas Bocas, municipality of Cariacica, Espírito Santo State, Southeast Brazil (Fig. 1). The area is comprised of protected Atlantic Rainforest biome, with lightly anthropized fragments.

Bats were captured and euthanized for this study by the authorization of State Institute for the Environment and Water Resources of Espírito Santo (IEMA-ES) (Research License GRN Number 026 ${ }^{\mathrm{a}}$-2017, Process Number 755612/1/16-Atualização) and by Chico Mendes Institute for Biodiversity Conservation of Brazilian Ministry of Environment (ICMBio/MMA) (Authorization for Scientific Purpose Activity Number 63023-1). Bats were captured for 7 consecutive d, between 0800 hours and 1600 hours with nets at sleeping sites, in artificial tunnels and natural caves, and at night, with mist nets. The nets were set up before dusk, around 1700 hours, and were checked every 20 min until 2300 hours, when they were closed. Captured bats were sedated with an intraperitoneal injection of $10 \%$ ketamine $(200 \mathrm{mg} / \mathrm{kg})$ and $2 \%$ xylazine $(20$ $\mathrm{mg} / \mathrm{kg}$ ) solution at a ratio of $2: 1$, and blood was collected by cardiac puncture and stored at
-20 C until DNA purification. Taxonomic identifications were based on analyses of skull and dental characters and on morphometric measurements (Moratelli et al. 2011; Reis et al. 2017; Loureiro et al. 2018). Subsequently, specimens were euthanized with $2.5 \%$ sodium thiopental $(120 \mathrm{mg} / \mathrm{kg})$ and spleen samples were collected and fixed in $99 \%$ pure isopropyl alcohol and submitted to DNA purification.

We isolated DNA from chiropteran blood and spleen samples using the DNeasy Blood and Tissue Kit (Qiagen, Hilden, Germany) and used as template for semi-nested PCR amplifications of Babesia/Theileria and Hepatozoon partial nuclear small-subunit ribosomal RNA (18S rRNA) gene (CriadoFornelio et al. 2003b). The PCR products of the expected size (approximately 410 base pairs; Criado-Fornelio et al. 2003a) were purified using the Wizard ${ }^{\circledR}$ SV Gel and PCR Clean-Up System (Promega, Madison, Wisconsin, USA) and sequenced with the BigDye $^{\text {TM }}$ Terminator-Cycle Sequencing Ready Reaction kit (Applied Biosystems, Carlsbad, California, USA) in an automatic sequencer (Applied Biosystems 3730xl DNA Analyzer). Sequences were edited using SeqMan software (DNASTAR Lasergene, Madison, Wisconsin, USA), and identity values were obtained using the Basic Local Alignment Search Tool (BLAST; National Center for Biotechnology Information 2018). Sequence alignment was performed using Clustal Omega (Madeira et al. 2019) and phylogenies were assessed applying the maximum-likelihood method, with T92+G correction model selected by MEGA version 7 software (Kumar et al. 2016), which was also used to produced phylogenetic trees from 1,000 bootstrap replicates for node support estimation.

We collected 34 Chiroptera specimens identified as the great fruit-eating bat (Artibeus lituratus), Seba's short-tailed bat (Carollia perspicillata), vampire bat (Desmodus rotundus), black mastiff bat (Molossus rufus), and black myotis (Myotis nigricans; Table 1). Of all examined bats, only one black mastiff bat was found parasitized by a female of Mesostigmata mite; however, the specimen 
TABLE 1. Detection of partial nuclear small-subunit ribosomal RNA (18S rRNA) gene of Hepatozoon sp. in bats from Biological Reserve of Duas Bocas, Espírito Santo State, Southeast Brazil, between 28 July and 10 August 2018

\begin{tabular}{|c|c|c|c|c|c|c|}
\hline \multirow{2}{*}{ Species } & \multicolumn{2}{|c|}{ Collected } & \multicolumn{4}{|c|}{ PCR-positive } \\
\hline & No. & $\%$ & Sample & No. & $\%$ & $95 \%$ Confidence Interval \\
\hline \multirow[t]{3}{*}{ Artibeus literatus } & \multirow[t]{3}{*}{4} & \multirow[t]{3}{*}{12} & Blood & 0 & 00.00 & $0.00,0.60$ \\
\hline & & & Spleen & 2 & 50.00 & $0.15,0.85$ \\
\hline & & & Total & 2 & 50.00 & $0.15,0.85$ \\
\hline \multirow[t]{3}{*}{ Carollia perspicillata } & \multirow[t]{3}{*}{11} & \multirow[t]{3}{*}{32} & Blood & 1 & 09.09 & $0.01,0.43$ \\
\hline & & & Spleen & 4 & 36.36 & $0.12,0.68$ \\
\hline & & & Total & 5 & 45.45 & $0.18,0.75$ \\
\hline \multirow[t]{3}{*}{ Desmodus rotundus } & \multirow[t]{3}{*}{2} & \multirow[t]{3}{*}{6} & Blood & 0 & 00.00 & $0.00,0.80$ \\
\hline & & & Spleen & 0 & 00.00 & $0.00,0.80$ \\
\hline & & & Total & 0 & 00.00 & $0.00,0.80$ \\
\hline \multirow[t]{3}{*}{ Molossus rufus } & \multirow[t]{3}{*}{16} & \multirow[t]{3}{*}{47} & Blood & 0 & 00.00 & $0.00,0.24$ \\
\hline & & & Spleen & 0 & 00.00 & $0.00,0.24$ \\
\hline & & & Total & 0 & 00.00 & $0.00,0.24$ \\
\hline \multirow[t]{3}{*}{ Myotis nigricans } & \multirow[t]{3}{*}{1} & \multirow[t]{3}{*}{3} & Blood & 0 & 00.00 & $0.00,0.94$ \\
\hline & & & Spleen & 0 & 00.00 & $0.00,0.94$ \\
\hline & & & Total & 0 & 00.00 & $0.00,0.94$ \\
\hline \multirow[t]{3}{*}{ Total } & \multirow[t]{3}{*}{34} & \multirow[t]{3}{*}{100} & Blood & 1 & 02.94 & $0.01,0.58$ \\
\hline & & & Spleen & 6 & 17.65 & $0.42,0.99$ \\
\hline & & & Total & 7 & 20.59 & $0.09,0.38$ \\
\hline
\end{tabular}

was damaged and further identification could not be performed.

Hepatozoon DNA was detected in one Seba's short-tailed bat blood sample and four spleen tissue samples; it was also detected in two great fruit-eating bat spleen tissue samples, totaling seven Hepatozoon-positive samples (Table 1). The BLAST analysis of Seba's short-tailed bat sequences that we obtained (MN369545, MN369546, and MN369547) showed 99\% identity (410/416, 402/408, and 403/409 base pairs, respectively) with $H$. canis (KU893123). In addition, the great fruiteating bat-derived sequences (MN369548 and MN369549) showed 99\% identity (407/ 411 and 406/411, respectively) with Hepatozoon sp. strain BV2 (AY600625) and BV1 (AY600626), originally isolated from a cricetid rodent in Spain. Indeed, our phylogenetic reconstructions supported grouping our Hepatozoon 18S rRNA sequences from Seba's short-tailed bat with the H. canis cluster from canids, and our Hepatozoon sequences from great fruit-eating bat with the Hepatozoon sp. BV2/BV1 cluster, from rodents (Fig. 2).

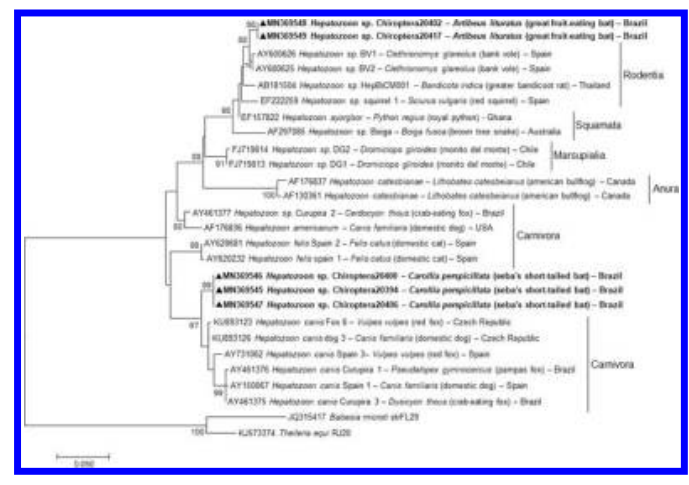

Figure 2. Phylogenetic inferences by maximumlikelihood method from 1,000 replicated trees based on nucleotide sequences of Hepatozoon 18s rRNA gene isolated of bats from Biological Reserve of Duas Bocas, Espírito Santo State, Southeast Brazil, between 28 July and 10 August 2018. Evolutionary distances were estimated by $\mathrm{T} 92+\mathrm{G}$ model. Bootstrap values greater than $70 \%$ are shown. Sequences obtained are highlighted with black triangle and GenBank accession numbers precede the sequence names. Scale bar indicates nucleotide substitutions per site. 
Immunologically, spleen is an important organ for vector-borne pathogen control, because it is the organ where several stages of $H$. canis are found and, together with the bone marrow, it is one of the most frequently parasitized organs, harboring chronic infections (Levine 1973; Levi et al. 2018). Here, we recorded a higher number of positive samples (six of seven positive samples) of Hepatozoon strains from spleen (Table 1) than blood, which was a better tissue for detection than blood in this study, as has been observed for other mammalian species (Hodžić et al. 2018; Levi et al. 2018). It was not possible to include the Hepatozoon sequences of Chiroptera from Malaysia (Pinto et al. 2013) in our alignments (Fig. 2) because these sequences represent a different portion of $18 \mathrm{~S}$ rRNA gene fragment than the sequences obtained in this study, impeding identification and comparison of the Chiroptera isolates.

In our study, nearly half of the great fruiteating bat and Seba's short-tailed bat captured were infected individuals (Table 1). This intrinsic relationship of Hepatozoon strains detected in the two infected Chiroptera species might be related to the enzootic cycle of each group, because spleen can harbor chronic infections (O'Dwyer 2011; Movilla et al. 2017; Levi et al. 2018), and due to the feeding habits and behavior of bats in the investigated area. The great fruit-eating bat is distributed throughout the Neotropical region, from Mexico to northern Argentina, including all regions of Brazil. The species is abundant in conserved areas as well as in altered and urban environments and, although primarily frugivores, can also feed on insects. Similarly, Seba's short-tailed bat is known to occur widely in the Neotropics, including all regions of Brazil, predominantly in altered and urban environments, feeding mainly on pepper plants (Piperaceae), but also able to feed on nectar and insects (Reis et al. 2007).

Although few studies investigating the tickborne protozoans infection have reported the presence of Hepatozoon in bats (Torres et al. 1983; Pinto et al. 2013), our results indicated that great fruit-eating bat and Seba's shorttailed bat are susceptible to infection by organisms genetically related to Hepatozoon sp. strain BV2 and H. canis, respectively, and probably, the hygienic practices of these mammals could increase Hepatozoon infection mechanisms via ingestion of infected hematophagus ectoparasites (Pinto et al. 2013).

It is not possible to establish a relation with vectors, paratenic, and reservoir hosts for Hepatozoon in this region, because these remain unknown. Further studies are needed to clarify whether Seba's short-tailed bat and great fruit-eating bat have any eco-epidemiologic importance in the cycle of these hemoparasites in Brazil.

Elizabeth C. F. Santos is a graduate fellow supported by supported by the Brazilian Federal Agency for Support and Evaluation of Graduate Education within the Ministry of Education of Brazil, and this work is part of her PhD thesis at Oswaldo Cruz Foundation, Brazil. The authors thank the Secretary of State for Health of Espírito Santo (Brazilian Ministry of Health) and the Laboratory of Biology and Parasitology of Reservoir Wild Mammals (Oswaldo Cruz Foundation, Brazil) for assistance on bat captures and sampling. We thank Dr. Daniela Dias (Wild Reservoir Taxonomy and Diagnosis Reference Service of Oswaldo Cruz Foundation, Brazil) for bat taxonomic identifications; to Genomic Platform DNA Sequencing (PDTIS/Oswaldo Cruz Foundation, Brazil) for sequencing support; and to Dr. Adrian Paul Ashton Barnett for the English review and comments on the manuscript. Financial support for the epidemiological survey for tick-borne pathogens investigation of wild hosts came from a project funded the Ministry of Health of Brazil.

\section{LITERATURE CITED}

Alencar NX, Kohayagawa A, Santarém VA. 1997. Hepatozoon canis infection of wild carnivores in Brazil Vet Parasitol 70:279-282.

Almeida AP, Souza TD, Marcili A, Labruna MB. 2013. Novel Ehrlichia and Hepatozoon agents infecting the crab-eating fox (Cerdocyon thous) in southeastern Brazil. J Med Entomol 50:640-646.

André MR, Adania CH, Teixeira RH, Vargas GH, Falcade M, Sousa L, Salles AR, Allegretti SM, Felippe PA, 
Machado RZ. 2010. Molecular detection of Hepatozoon spp. in Brazilian and exotic wild carnivores. Vet Parasitol 173:134-138.

-Azevedo Gomes L, Moraes LA, Figueira Aguiar DC, Tavares Dias HL, Sardinha Ribeiro AS, Piram do Couto Rocha H, Teixeira Nunes MR, Costa Gonçalves E. 2018. Genetic diversity of Hepatozoon spp. in Hydrochoerus hydrochaeris and Pecari tajacu from eastern Amazon. Ticks Tick-Borne Dis 9:314-318.

-Criado-Fornelio A, Martinez-Marcos A, Buling-Saraña A, Barba-Carretero JC. 2003a. Molecular studies on Babesia, Theileria and Hepatozoon in southern Europe. Part I. Epizootiological aspects. Vet Parasitol 113:189-201.

Criado-Fornelio A, Martinez-Marcos A, Buling-Saraña A, Barba-Carretero JC. 2003b. Presence of Mycoplasma haemofelis, Mycoplasma haemominutum and piroplasmids in cats from southern Europe: A molecular study. Vet Microbiol 93:307-317.

Dantas-Torres F. 2008. Canine vector-borne diseases in Brazil. Parasit Vectors 1:25.

-Demoner LC, Magro NM, Silva MRL, Antunes JMAP, Calabuig CIP, O’Dwyer LH. 2016. Hepatozoon spp. infections in wild rodents in an area of endemic canine hepatozoonosis in southeastern Brazil. Ticks Tick-Borne Dis 7:859-864

-Hodžić A, Mrowietz N, Cézanne R, Bruckschwaiger P, Punz S, Habler VE, Tomsik V, Lazar J, Duscher GG, Glawischnig W, et al. 2018. Occurrence and diversity of arthropod-transmitted pathogens in red foxes (Vulpes vulpes) in western Austria, and possible vertical (transplacental) transmission of Hepatozoon canis. Parasitology 145:335-344.

-Kumar S, Stecher G, Tamura K. 2016. MEGA7: Molecular evolutionary genetics analysis version 7.0 for bigger datasets. Mol Biol Evol 33:1870-1874.

Levi MM, Nachum-Biala Y, King R, Baneth G. 2018. A survey of Babesia spp. and Hepatozoon spp. in wild canids in Israel. Parasit Vectors 11:150.

Levine ND. 1973. Protozoan parasites of domestic animals and of man. 2nd Ed. Burgess Publishing, Minneapolis, Minnesota, 406 pp.

- Loureiro LO, Gregorin R, Perini FA. 2018. Diversity, morphological phylogeny, and distribution of bats of the genus Molossus E. Geoffroy, 1805 (Chiroptera, Molossidae) in Brazil. Zoosystema 40:425-452.

Madeira F, Park YM, Lee J, Buso N, Gur T, Madhusoodanan N, Basutkar P, Tivey ARN, Potter, SC, Finn RD, et al. 2019. The EMBL-EBI search and sequence analysis tools APIs in 2019. Nucleic Acids Res 47:W636-W641.

- Maia JP, Álvares F, Boratyński Z, Brito JC, Leite JV, Harris DJ. 2014. Molecular assessment of Hepatozoon (Apicomplexa: Adeleorina) infections in canids and rodents from North Africa, with implications to transmission dynamics across distinct taxonomic groups. J Wildl Dis 50:837-848.

-Moratelli R, Peracchi AL, Dias D, Oliveira JA. 2011. Geographic variation in South American populations of Myotis nigricans (Schinz, 1821) (Chiroptera, Vespertilionidae), with the description of two new species. Mamm Biol 76:592-607.

Movilla R, Altet L, Serrano L, Tabar M-D, Roura X. 2017. Molecular detection of vector-borne pathogens in blood and splenic samples from dogs with splenic disease. Parasit Vectors 10:131.

National Center for Biotechnology Information. 2018. Basic Local Alignment Search Tool (BLAST). http:// blast.ncbi.nlm.nih.gov/BLAST.CGI. Accessed September 2018

O’Dwyer LH. 2011. Brazilian canine hepatozoonosis. Rev Bras Parasitol Vet 20:181-193.

Perles L, Roque ALR, D'Andrea PS, Lemos ERS, Santos AF, Morales AC, Machado RZ, André MR 2019. Genetic diversity of Hepatozoon spp. in rodents from Brazil. Sci Rep 9:10122.

Pinto CM, Helgen KM, Fleischer RC, Perkins SL. 2013. Hepatozoon parasites (Apicomplexa: Adeleorina) in bats. J Parasitol 99:722-724.

Reis NR, Peracchi AL, Batista CB, Lima IP, Pereira AD, editors. 2017. História natural dos morcegos Brasileiros: chave de identificação de espécies. 1st $\mathrm{Ed}$. Technical Books Editora Ltda., Rio de Janeiro, Brazil, $253 \mathrm{pp}$

Reis NR, Perachi AL, Pedro WA, Lima IP, editors. 2007. Morcegos do Brasil. Univesidade Estadual de Londrina, Londrina, Paraná, Brazil, 256 pp.

Rubini AS, Paduan KS, Cavalcante GG, Ribolla PEM, O'Dwyer LH. 2005. Molecular identification and characterization of canine Hepatozoon species from Brazil. Parasitol Res 97:91-93.

- Serra Freire NM. 1979. Babesia ernestoi sp. n., in Didelphis marsupialis L., 1758, and D. albiventris Lund, 1841, in Brazil. Zentralbl Veterinarmed B 26: 614-622.

Silva MRL, Fornazari F, Demoner LC, Teixeira CR, Langoni H, O’Dwyer LH. 2017. Didelphis albiventris naturally infected with Hepatozoon canis in southeastern Brazil. Ticks Tick-Borne Dis 6:878-881.

Smith TG. 1996. The genus Hepatozoon (Apicomplexa: Adeleina). J Parasitol 82:565-585.

Torres DMAGV, Dias RMS, Chieffi PP, Tolezano JE, Nagamori AH. 1983. Hemoparasitas de quirópteros e marsupiais capturados no estado de São Paulo, Brasil. Rev Inst Aldof Lutz 43:47-53.

Submitted for publication 27 August 2019.

Accepted 11 December 2019. 